\title{
Adherence to healthy habits and academic performance in Vocational Education Students Adherencia a hábitos saludables y Rendimiento Académico en estudiantes de Formación Profesional \\ *Carlos Enrique López-Nuevo, * Joaquín Sanchez-M olina, **Germán Díaz U reña \\ *Universidad Europea de Madrid (España), **Universidad Francisco deVitoria (España)
}

\begin{abstract}
The purpose of the present cross-sectional study was to analyze the relationship between adherence to healthy lifestyles and academic performance in students of differentVocational Education and Training (VET) degrees. M ethods: 55 Vocational Education students' from theAnimation and Physical-SportsActivities Course (n 28) and from Dental Pathology and the Prosthetic Anatomy courses (DPPA) (n 27), were analyzed through the G-PAQ and the KIDMED questionnaires, to asesstheir adherence to Physical Activity and to Mediterranean diet. In addition, anthropometric dataand academic qualifications were correlated. Results: APSA students scored significantly higher in M editerranean diet adherence, as well as in the number of minutes of vigorous and moderate intensity aerobic exercise. DPPA students obtained significantly higher values in sedentary activities. No significant differences were found in the academic performance of both groups. Conclusion: the practice of PA was positively correlated with a greater adher ence to M editerranean diet. This fact entail sa factor of prevention of cardiovascular and metabolic disease in the future. Thus, the implementation of nutritional education and PA programs for VET students is suggested.
\end{abstract}

Keywords: Physical Activity, M editerranean Diet, Academic Performance, Lifestyle, Students.

Resumen. El objetivo del presente estudio fue analizar la relación entre la adherencia a estilos de vida saludables y el rendimiento académico en estudiantes de diferentes titulaciones de Formación Profesional (FP). M étodo: 55 estudiantes del curso deA nimación y ActividadesFísico-D eportivas (TAFAD) (n 28) y de los cursos de Patología D ental yA natomía Protésica (DPPA) (n 27), fueron analizados a través de los cuestionarios G-PAQ y KIDMED, para valorar su adherencia a laActividad Física y a la dieta mediterránea. Además, se correlacionaron datos antropométricos y calificaciones académicas. Resultados: Los estudiantes deTAFAD obtuvieron puntuaciones significativamente más altas en la adherencia a la dieta mediter ránea, así como en la cantidad de minutos de ejercicio aeróbico vigoroso y de intensidad moderada. Losal umnos de la DPPA obtuvieron valores significativamente más al tos en actividades sedentarias; no se encontraron diferencias significativas en el rendimiento académico de ambos grupos. Conclusión: la práctica deAF se correlacionó positivamente con una mayor adherenciaa la dieta mediterránea. Este hecho conlleva un factor de prevención de enfermedades cardiovasculares y metabólicas en el futuro. Por tanto, se sugiere la implementación de programas de educación nutricional yAF para estudiantes de FP.

Palabras clave: Actividad física, Dieta mediterránea, Rendimiento académico, Estilo de vida, Estudiantes.

\section{Introduction}

Physical Activity (PA) has traditionally been related to the increase in daily energy expenditure derived from the activation, spontaneously or voluntarily, of the musculoskeletal system, triggering an increase in the basal metabolic rate (Claros et al., 2011). The World Health 0 rganization (W HO) determined that PA was the key factor to prevent chronic diseases related to inactivity and sedentary lifestyle (W HO, 2010). Nevertheless, the 66 th United Nations General Assembly (UNO, 2011), reported that 9 out of 10 deaths

Fecha recepción: 12-01-21. Fecha de aceptación: 05-03-21

Carlos Enrique López Nuevo

carlosenrique.lopez@ universidadeuropea.es in Spain occurred due to chronic pathologies such as diabetes, cardiovascular disease and cancer, all of them related in some way to physical inactivity. In this sense, the European Commission evinced that $44 \%$ of the Spanish population never or rarely, practiced PA or any type of sport (European Comission, 2014). Among Spanish students', there is also a worrying prospect, predominating a low level of sports-physical activity (Abarca-Sos, Julián Clemente, M urillo, Generelo \& Zaragoza, 2015).

The benefits that PA provides are unquestionable, so it is the positive relationship that its continued practice (e.g. aerobic exercise) generates in different psychological, social or cognitive processes (Estrada et al., 2016; Stillman, Esteban-Cornejo, Brown, Bender \& Erickson, 2020). At early ages, it is also verified that 
adequate levels of physical activity provide optimal physiological development during growth stages, help prevent childhood depressive symptoms (Rothon et al., 2010) and allow this age population to keep numerous health benefits (Janssen \& LeBlanc, 2010). However, in last years, sedentary activities have settled down in our society, mainly in youngsters, which not only generate a risk of suffering metabolic and cardiovascular early diseases (C esa et al. 2015), but al so influence negatively on their cognitive efficacy (Fedewa\&Ahn, 2011; Zavala Crichton et al., 2020). In this sense, the studies carried out thus far, indicate that cardiovascular exercise is possibly the most effective in improving cognitive function in children and young people (Esteban-Cornejo et al. 2014). However, more research is needed to determine if strength exercise or other specific types of exercise have the same benefits. In fact, recent literature indicate that cardiovascular-type PA can improve certain cognitive aspects in children and adolescents (Hillman et al. 2014), improving results in cognitive tests and showing specific structural and functional adaptationsin brain-involved areas within the cognitive tasks used. Likewise, different studies have shown an improvement in the results in children and adolescents as a consequence of performing physical activity in different mathematical (Ardoy et al. 2014), competency (Rasberry et al., 2011), attention (Kubesch et al., 2009) and explicit memory (Chaddock et al., 2010) tests. In this last study by Chaddock et al. (2010), it was demonstrated that those young people with greater cardiovascular capacity increased the volume of their hippocampus, and therefore performed better in the tasks that required explicit memory.

Healthy diet (type, quantity and quality of food eaten) and regular exercise are the foundations of healthy lifestyle. The Mediterranean diet represents a combination of fresh and seasonal food and has traditionally provided contrasted benefits to human health (DuráTravé \& Castroviejo Gandarias, 2011). Also, being related with lower incidence of cardiovascular diseases (Arós \& Estruch, 2013; Carrillo Fernández, Dalmau Serra, M artínez Álvarez, SolàAlberich \& Pérez Jiménez, 2011). Different studies endorse the consumption of this type of food, rich in antioxidants and with beneficial properties on the inflammatory response and endothelial function; also allowing a decrease in the post-pandrial blood glucose peak, which would mean a decrease in the incidence of pathologies like Diabetes M ellitus (Salas-Salvadó, Rubio, Barbany \& Moreno, 2007). M editerranean diet, has been also found effective in prevention and treatment of overweight and obesity (D'Innocenzo, Biagi \& Lanari, 2019). These chronic conditions represent one of the main epidemics today, being responsible for other cardiovascular, metabolic and cancer related diseases (W HO, 2015). Among M editerranean diet key factors, we find a great source of vitamins and water with a low energy density and even the feeling of fullness provided by the foods that compose it (mainly fruitsand vegetables) (M artinezGonzalez et al. 2015). However, sociological and cultural changes in recent decades have led to inevitable changes in food preferences, especially in young people and adolescents, who favour processed foods that entail an excess of refined sugars and lead to a considerable increase in cholesterol (Bollat M ontenegro \& DuráTravé, 2008).

Q uestionnaires, are traditional methods for assessing PA and energy expenditure, specially when it comes to establishing relationships with subjects' health and lifestyle; they also represent low costs and little effort for the analyzed subject (O rdax \& Terrados, 2006). The G-PAQ (Global Assessment Q uestionnaire for PA) assesses PA levels considering 3 points of view: occupational, related to transportation and physical activity in free time, embracing various components such as intensity (measured in METs or metabolic equivalent), duration (measured in minutes) and frequency (days of the week). This questionnaire has been validated to monitor PA in adult subjects from the health scope (Armstrong \& Bull, 2006) The KIDM ED questionnaire on eating habits, has been frequently used to assess the nutritional status of young subjects (M olina, 2021; Rosado, Fernández \& López, 2020).

The multidimensional nature of academic performance (AP) hamper its holistic definition, since it comes determined by personal (intrinsic and extrinsic academic motivation, causal attributions and perceptions of control), social (family environment, socio-economic context, cultural capital) and institutional factors(Vargas, 2007). Some authors defend and advocate for the qualifications as the final expression that definesAP, even though they explain that it isthe result of a multifactorial process (Dogan, 2015). Likewise, the relationships between healthy habits and $A P$, described in some recent studies (Adelantado-Renau, Jiménez-Pavón, BeltranValls \& Moliner-U rdiales, 2019; Iglesias, del Pozo \& López, 2019), suggest the implementation by school centers of more resources to grant the possibility of arising students' physical activity time. In the same way, previous investigation has linked the participation in 
team sports with the enhance in AP (M annino et al., 2019). Thus, on the basis of recent investigation and evaluating the current perspective of our society, it seems necessary to implement strategies that involve a greater amount of physical activity among our young people (Wald, Muennig, O 'Connell \& Garber, 2014), in order to minimize the risk of suffering early diseases, and at the same time, improve cognitive development during the learning process.

Given the importance of exercise, and adherecence to good eating habits in youngsters, the knowledge of the posible impact of this factors in theAP of students is far from being extensive. For this reason, the current research aimed to analyze the relationship between adherence to healthy lifestyles (including dietary patterns, and sports practice habits) and the academic performance in students of differentVocational Education Programs. The initial hypothesis was that kidmed score, would correlate positively with students' PA levels and qual ifications (AP).

\section{Material and Methods}

\section{Subjets}

The proposed design is obser vational through crosssectional surveys. The sample consisted of fifty-five students belonging to three different fields of European University of Madrid's Vocational Education Training (VET) Programs. The sample was divided into two groups according to their field of study: 28 studentsfrom the Animation and Physical-Sports Activities (APSA) cycle (21 \pm 3 yearsold, $22.59 \pm 2.77 \mathrm{BM} \mathrm{I}$ ), and 27 students from the Dental Pathology and the Prosthetic Anatomy (DPPA) education cycles ( $23 \pm 2$ years old, $21.79 \pm 3.5$ BMI). From 62 initial disposed participants, 55 valid questionnaires were finally collected. The inclusion criteria were the belonging to the respective education cycles, aiming to enquire any possible correlations between healthy lifestyles (including dietary, and PA habits) and the academic performance. There were no exclusion criteria for whatever reason: age, health, occupation, or PA level. A correlational study was carried out, to relate different variables in connection with lifestyle and academic performance.

All the analyzed subjects were over 18 years old at the time of the study and signed the informed consent (IC) developed for this purpose.

\section{Instruments and Procedure}

To collect the information related to the amount of weekly Physical Activity, the G-PAQ questionnaire (Global Physical Activity Q uestionnaire) was used, which gives validity and reliability to assess the level of Physical Activity in adult subjects (short-term testretest reliability ranged from 0.83 to 0.96 ) (Herrmann, Heumann, Der Ananian \&Ainsworth, 2013). In this same document the following questions were attached:

- Age, weight, height.

- Qualification: average mark obtained in the first quarter of the academic year 2017/ 18.

- Practice of any team/ group sport, at least 2 days a week.

To collect information regarding adherence to the Mediterranean diet, the KIDMED questionnaire (validated for subjects between 6 and 24 years old) (Serra-Majem et al. , 2004) was used. This questionnaire al so details sthe gender, height and weight of the subjects.

The test analyze 16 items that determine a final score between 0-12 points (Kidmed index) for adherence to the Mediterranean diet. A score bel ow 3 is considered «low adherence»; between 4-7 points, is considered «moderate adherence»; while a score above 8 is considered «high adherence» to the M editerranean diet. The test scores each item with 0, 1 or -1 points depending on the answer. It is noteworthy the 4 items that score negative: "Goes more than once a week to a fast-food (hamburger)»; «Skips breakfast»; «H as commercially baked goods o pastries for breakfast», «Takes sweets and candy several times every day». The rest of the items score 01 points, depending on the answer (yes / no) provided.

\section{Statistic analysis}

Statistical analysis was performed with the SPSS23.0 statistical program. For the analysis of the descriptive statistics, the value of the M edian (Q 1-Q 3) of each va riable were calculated (since the variables met the nonparametric normality criteria); except for «moderate PA time» where mean \pm SD was calculated. For the inferential analysis, after checking sample normality using the Kolmogorov-Smirnov statistic, the differences between the two groups were calculated. For variables with a nonparametric distribution, the Mann-W hitney $U$ test was used. For variables with a parametric distribution, the T test for independent samples was used. For the correlational analysis, Spearman's rho was used. A confidence level of $p<0.05$ was set.

\section{Results}

After checking normal ity through the Kolmogorov- 
Smirnov test, all variables except «moderate PA time» presented a non-normal distribution. Descriptive analyses are presented in Table 1.

Table 1.

Results of the investigation. Me (Q1-Q3) and mean comparison between both groups

\begin{tabular}{|c|c|c|c|c|c|c|}
\hline & \multicolumn{2}{|c|}{ APSA $(n=28)$} & \multicolumn{2}{|c|}{ DPPA $(n=27)$} & \multirow[b]{2}{*}{ Z/ t-value } & \multirow[b]{2}{*}{$p$} \\
\hline & Me & Q1-Q3 & $\mathrm{Me}$ & Q1-Q3 & & \\
\hline BMI & 22.96 & $20.04-23.93$ & 21.09 & $19.13-24.30$ & -1.07 & 0.37 \\
\hline ACADEMIC GRADES & 6.95 & $6.30-7.30$ & 7.00 & $6.00-8.00$ & -0.49 & 0.63 \\
\hline KIDMED SCORE & 8.00 & $7.00-10.00$ & 6.00 & $4.00-8.00$ & -2.56 & 0.01 \\
\hline VIGORO US PA (minutes) & 405.00 & $303.75-562.50$ & .00 & $.00-120.00$ & -5.29 & $<0.01$ \\
\hline TIME SEDENTARY (minutes) & 120.00 & $112.50-300.00$ & 400.00 & $360.00-480.00$ & -5.40 & $<0.01$ \\
\hline VIGORO USPA (days/ week) & 5.00 & $3.75-7.00$ & .00 & $.00-2.00$ & -4.94 & $<0.01$ \\
\hline MODERATE PA (days/ week) & 5.50 & $4.00-7.00$ & 2.00 & $.00-5.00$ & -4.75 & $<0.01$ \\
\hline & & SD & & SD & Z/ t-value & $P$ \\
\hline MODERATE PA (minutes) & 297.14 & 159.35 & 102.96 & 127.67 & -4.40 & $<0.01$ \\
\hline AGE (years) & 21,21 & 2,92 & 22,88 & 2,32 & $-2,74$ & $<0,01$ \\
\hline BMI & 22,59 & 2,77 & 21,79 & 3,50 & 0,89 & 0,37 \\
\hline
\end{tabular}

Statistically significant values are in bold

There were significant differences in the average age of both groups, being higher in the group of DPPA students. There were no significant differences in both groups in relation to the grade obtained after the first quarter of the course that they were studying at the time of data collection.

Regarding the KIDMED score, which determines adherence to the Mediterranean diet, we observed significant differences in both groups; the group of APSA students obtained a score of 8.00 that determines a high adherence to the M editerranean diet. The DPPA course students, obtained ascore of 6.00 (moderate adherence).

APSA students scored significantly higher in Mediterranean diet adherence, as well as in the number of minutes of vigorous and moderate intensity aerobic exercise. DPPA students obtained significantly higher values in sedentarism.

There were significant differences in both groups in relation to the number of minutes of vigorous and moderate intensity aerobic PA, observing far higher values in both cases in the group of APSA students. However, this relationship is inverse observing the results of the number of minutes per week dedicated to sedentary activities In thiscase, DPPA group of students obtained significantly higher values. Likewise, we

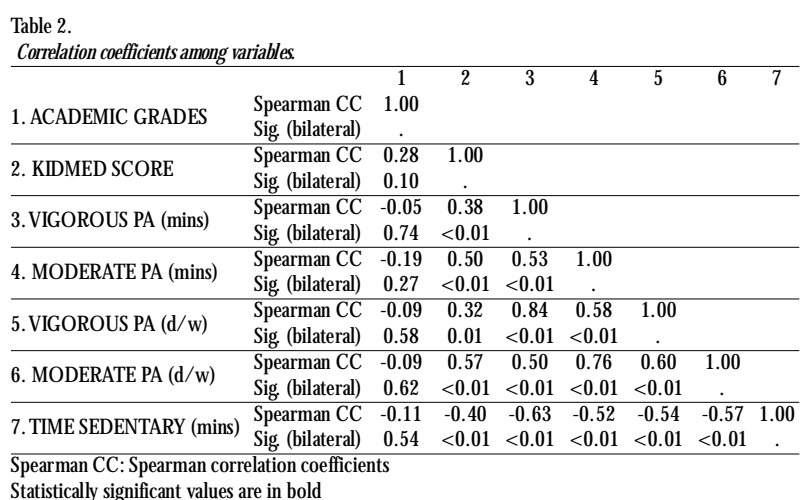

observed significant differencesin relation to the weekly frequency of PA. APSA group obtained significantly higher values.

Spearman's rho correlations between the analyzed variables, are described in Table 2

A significant moderate correlation was observed between daily time spent in moderate and vigorous PA and adherence to KIDMED score. A moderate correlation is observed between moderate and vigorous PA and adherence to KIDMED score; both correlations are also statistically significant. It is also worth noting an inverse correlation between sedentary behavior and adherence to the Mediterranean diet; this correlation is also statistically significant.

\section{Discusion}

The present research aimed to analyze the relationship between adherence to healthy lifestyles (including dietary patterns, and PA) and the academic performancein students of differentVocational Education Programs. O ur departure hypothesis was partially confirmed since the kidmed scores correlated with the time and intensity of PA, though not finding relation with the academic grades.

In terms of health, W HO implemented several minimum PA recommendations to the general population between 18 and 64 year sold to prevent and/ or avoid adverse consequences in the medium-long term. At least 150 minutes (preferably 300) of moderate aerobic physical activity (3-6 METS) or 75 minutes (preferably 150) of vigorous æerobic PA (> 6 METS) per week is underscored (W HO, 2010). In our study, the subjects analyzed in the APSA course, exceed these recommendations ( 405 and 300 minutes of vigorous and moderate PA/ week). However, DPPA students do not reach these recommended minimums ( 0 and 110 minutes of vigorous and moderate PA/ week), which means being at health hazard if they maintain this behavior for at least 3 consecutive months (Ferguson, 2014). In fact, the maintenance of such conducts, would imply reaching a positive energy balance that can lead, in the long term, to an increase in the body mass index (BMI) and theamount of accumulated fat. Both associated with the development of other comorbidities such as high blood pressure, metabolic diseases, heart disease and some types of cancer (Alvero-Cruz et al., 2010).

Values showed in present investigation, are proportionally similar to those found in previous research, in which the levels of PA in Physical Education 
Degree students' were compared to other university degrees (Farinola \& Bazán, 2010; Solera Sánchez \& Gamero Lluna, 2019), and where al so, G-PAQ test was used for data collection. Significant differences were observed in thisregard, since Physical Education students achieved an average of 159 minutesa day of PA (including moderate and vigorous), while students from other degrees only achieved an average of 57 minutes a day. In our present project, APSA students achieved an average of 100.71 minutes/ day of $P A$, while other courses students reached only 15.71 minutes daily on average (average of Median minutes moderate and vigorous weekly PA, per day). According to Physical Activity GuidelinesAdvisory Committee (2018), those subjects who reach more than 700 minutes/ week, asthe subjects in the APSA group, significantly reduce the risk of mortality from any cause. However, the group of students from other VET programs, with only 185 minutes/ week, exponentially increase the relative mortality risk.

Another similar study in which 167 university students (Rangel Caballero, Rojas Sánchez \& Gamboa Delgado, 2015) were analyzed, determined an average of 137 minutes/ day of activity, being significantly higher than those of our Project. However, the average sedentary timewas 527 minutes/day, significantly higher than both groups in our present study. The BMI value was 23.2, slightly higher than those obtained in our study (22.96 (20.04-23.93) and (21.09 (19.13-24.30). Farinola and Bazán (2010) analyzed 425 unergraduates in a pilot study, in which sedentary behaviors were assessed using the G-PAQ questionnaire. These authorsfound an inverse relationship between activity time and sedentary behavior time. In fact, they observed how students who spent less inactive time, had more high-intensity PA time, an aspect that is evinced in our study.

Dental prosthetics and pathological anatomy (DPPA) students stated a moderate score in KIDMED questionnaire(Table 1). Wealso found thispoor KIDMED score, up to the $62.1 \%$ of 570 undergraduates (Durá Travé \& Castroviejo Gandarias, 2011). APSA students presented a Median value of 8 (7-10), matching a moderate-high adherence. In another similar study (De laM ontaña, Castro, Cobas, Rodríguez \& Míguez, 2012), where 266 undergraduates were analyzed, and the sample was stratified according to their BMI, authors detected in those students with normal weight (i.e. BM I between 18.5 and 24.9) (Salas-Salvadó et al., 2007), a Kidmed index value of 6.51 . This is slightly lower than our sample Median average value (7.00).
Notwithstanding, higher than DPPA students (6.00), and significantly lower than APSA students' indexes (8.00).

Several authors have observed certain macro and micronutrient deficits in the university population (Soler, Chávez \& Godoy-Cumillaf, 2019), despite their linkage with the health field (Rizo-Baeza, GonzálezBrauer \& Cortés, 2014). In our study, those students with low adherence to the Mediterranean diet reported at least a low contribution of micronutrients, at the expense of being analyzed through dietary reminders, as advisable tool in these cases (Salvador et al., 2006). In another study (Rodrigo Vega, Ejeda Manzanera, Panero, del Pilar \& M ijancos Gurruchaga, 2014) where 216 Nursing students were analyzed before and after their graduation, a positive evolution of the KIDMED score «pre» and «post» degree, was observed (4.765.33). Even so, adherence remained moderate-low, as well as our non-APSA students. This also suggests that in most degrees, an early educational intervention is essential from a nutritional viewpoint.

According to the Spanish Ministry of Education, Culture and Sports, there is a relationship between higher level of education and higher amount of PA. Although this data, obtained in subjects over 25 years old, could be associated with the higher-level-education population's progressive awareness of the benefits provided by PA, it is a fact that, the Spanish undergraduated population does not achieve the recommended PA (MECDE, 2014). However, these conditions were neither found nor correlate amongVET students' AP in relation with the amount of physical exercise. We can by contrast, verify a greater adherence to healthy lifestyles in those related to PA courses' students (APSA), in contrast to the rest of the students, who did not meet minimum recommendations established by the W HO, and present an unprofitable adherence to the Mediterranean diet.

In conclusion, in the present study, no relationship was found between the students' academic grades and the adherence to Mediterranean diet, or either to the fact of performing more or less PA. However, we have observed a significant correlation between those subjects who carry out more PA with greater adherence to the Mediterranean diet. In view of these results, we can suggest the development and implementation of nutritional education and PA programsforVET students, as it's al ready been suggested in early ages population (Molina, 2021). 


\section{Limitations of study and future research lines}

The principal limitations of the present research were the small sample size analyzed and the limitations in time, since it was only assessed a term of the academic year. We propose the approach of a prolonged study, and with a wider sample. Future research might seek to address these issues.

\section{Conclusions}

No relationship was found between the students grades and the adherence to Mediterranean diet, or either to the weekly amount of PA. However, we found a significant correlation between PA and higher score in KIDMED i.e. adherence to Mediterranean diet. Students, who carry out more PA stated greater adherence to the Mediterranean diet.

In view of these results, we suggest the implementation of nutritional education and PA programs for VET students. This aspect may involve a protection factor against cardiovascular and/ or metabolic diseases in the future, but not involving harm or decrease in their academic performance.

\section{References}

Abarca-S0s, A., Julián Clemente, J. A., M urillo, B., Generelo, E., \& Zaragoza, J. (2015). La Educación Física: ¿ Una oportunidad para la promoción de la actividad física? Retos: N uevas Tendencias En Educación Física, Deportey Recreación, 28, 155-159.

Adelantado-Renau, M., Jiménez-Pavón, D., BeltranValls, M. R., \& Moliner-Urdiales, D. (2019). Independent and combined influence of healthy lifestyle factors on academic performance in adolescents: DAD OS Study. Pediatric Research, 85(4), 456- 462. https:/ / doi.org/ 10.1038/ s41390-019$0285-z$

Alvero-Cruz, J. R., Álvarez Carnero, E., FernándezGarcía, J. C., Barrera Expósito, J., Carrillo de Albornoz Gil, M., \& Sardinha, L. B. (2010). Validez de los índices de masa corporal y de masa grasa como indicadores de sobrepeso en adolescentes españoles: estudio Esccola. Medicina Clínica, 135(1), 8-14. https: / / doi.org/ 10.1016/ j.medcli.2010.01.017

Ardoy, D. N., Fernández-Rodríguez, J. M., JiménezPavón, D., Castillo, R., Ruiz, J. R., \& O rtega, F. B. (2014). A Physical Education trial improves adolescents' cognitive performance and academic achievement: the EDU FIT study. Scandinavian Journal of M edicine\& Sciencein Sports, 24(1), e52-e61. https:/ / doi.org/ 10.1111/ sms. 12093

Armstrong, T., \& Bull, F. (2006). Development of the World Health O rganization Global Physical Activity Q uestionnaire (GPAQ). Journal of Public $H$ ealth, 14(2), 66-70. https:/ / doi. org/ 10.1007/ s10389-0060024-X

Arós, F., \& Estruch, R. (2013). Dieta mediterránea y prevención de la enfermedad cardiovascular. Revista Española de Cardiología, 66(10), 771-774. https:/ / doi.org/ 10.1016/ j.recesp. 2013.04.026

Bollat Montenegro, P., \& DuráTravé, T. (2008). Modelo dietético de los universitarios. Nutrición Hospitalaria, 23(6), 626-627.

Carrillo Fernández, L., Dalmau Serra, J., Martínez Álvarez, J. R., SolàAlberich, R., \& Pérez Jiménez, F. (2011). Grasas de la dieta y salud cardiovascular. Clínica e Investigación En Arteriosclerosis, 23, 1-36. https:/ / doi.org/ 10.1016/ S0214-9168(11)70001-8

Cesa, C. C., Barbiero, S. M., Petkowicz, R. de 0., Martins, C. C., Marques, R. dasV., Andreolla, A. A. M., \& Pellanda, L. C. (2015). Effectiveness of Physical Exercise to Reduce Cardiovascular Risk Factors in Youths: A Randomized Clinical Trial. Journal of Clinical Medicine Ressarch, 7(5), 348-355. https:/ / doi.org/ 10.14740/ jocmr1700w

Chaddock, L., Erickson, K. I., Prakash, R. S., Kim, J. S. ,Voss, M. W., VanPatter, M., Pontifex, M. B., Raine, L. B., Konkel, A., Hillman, C. H., Cohen, N. J., \& Kramer, A. F. (2010). A neuroimaging investigation of the association between aerobic fitness, hippocampal volume, and memory performance in preadolescent children. Brain Research, 1358, 172183. https:// doi.org/ 10.1016/ j.brainres.2010.08.049

Claros, J. A. V., Álvarez, C. V., Cuellar, C. S., \& Mora, M. L. A. (2011). Actividad física: estrategia de promoción de la salud. Revista Hacia La Promoción de La Salud, 16(1), 202-218.

D'Innocenzo, S., Biagi, C., \& Lanari, M. (2019). 0 besity and the Mediterranean Diet: A Review of Evidence of the Role and Sustainability of the Mediterranean Diet. Nutrients, 11(6). https:/ / doi.org/ 10.3390/ nu11061306

De la Montaña, J., Castro, L., Cobas, N., Rodríguez, M., \& Míguez, M. (2012). Adherencia ala dietamediterránea y su relación con el índice de masa corporal en universitarios de Galicia. Nutr Clin Diet H osp, 
$32(3), 72-80$.

Dogan, U. (2015). Student engagement, academic selfefficacy, and academic motivation as predictors of academic performance. TheAnthropologist, 20(3), 553561.

DuráTravé, T., \& Castroviejo Gandarias, A. (2011). Adherencia a la dieta mediterránea en la población universitaria. N utrición H ospitalaria, 26(3), 602-608.

Esteban-Cornejo, I., Tejero-González, C. M., M artinezGomez, D., Del-Campo, J., González-Galo, A., Padilla-M oledo, C. , Sallis, J. F., \&Veiga, O. L. (2014). Independent and Combined Influence of the Components of Physical Fitness on Academic Performance in Youth. The Journal of Pediatrics, 165(2), 306-312.e2. https:// doi.org/ 10.1016/ j.jpeds. 2014.04.044

Estrada, P. R., Vázquez, E. I. A., Gáleas, Á. M. V., Ortega, I. M. J., Serrano, M. D. L. P., \& Acosta, J. J. M. (2016). Beneficios psicológicos de la actividad física en el trabajo de un centro educativo. Retos: Nuevas Tendencias En Educación Física, D eportey Recreación, 30, 203-206.

European Comission. (2014). Special Eurobarometer 412: Sport and physical activity - Datasets.

Farinola, M ., \& Bazán, N. (2010). Niveles de actividad física en estudiantes de la carrera de profesorado universitario en educación física y de otras carreras de grado en la U niversidad de Flores. Calidad deVida y Salud, 3(1).

Fedewa, A. L., \&Ahn, S. (2011). The Effects of Physical Activity and Physical Fitness on Children's Achievement and Cognitive $O$ utcomes. Research Quarterly for Exerciseand Sport, 82 (3), 521-535. https:/ / doi.org/ 10.1080/ 02701367.2011.10599785

Ferguson, B. (2014). ACSM 's guidelines for exercise testing and prescription 9th Ed. 2014. The Journal of the Canadian Chiropractic Association, 58(3), 328.

Garbanzo Vargas, G. M. (2012). Factores asociados al rendimiento académico en estudiantes universita rios, una reflexión desde la calidad de la educación superior pública. Revista Educación, 31 (1), 43. https:/ / doi.org/ 10.15517/ revedu. v31i1.1252

Herrmann, S. D., Heumann, K. J., Der Ananian, C. A., \& Ainsworth, B. E. (2013). Validity and reliability of the global physical activity questionnaire (GPAQ). Measurement in Physical Education and Exercise Science, 17(3), 221-235. doi:10.1080/ 1091367X.2013.805139

Hillman, C. H., Pontifex, M. B., Castelli, D. M., Khan, N. A., Raine, L. B., Scudder, M. R., Drollette, E.
S., Moore, R. D., Wu, C.-T., \& Kamijo, K. (2014). Effects of the FITKids Randomized Controlled Trial on Executive Control and Brain Function. PEDIATRICS, 134(4), e1063-e1071. https:/ / doi.org/ 10.1542/ peds.2013-3219

Iglesias, Á., del Pozo, E. M. P., \& López, J. M. (2019). Prevalencia de sobrepeso y obesidad, hábitos alimentarios y actividad física y su relación sobre el rendimiento académico. Retos: Nuevas Tendencias En Educación Física, D eporte y Recreación, 36, 167-173.

Janssen, I., \& LeBlanc, A. G. (2010). Systematic review of the health benefits of physical activity and fitness in school-aged children and youth. International Journal of Behavioral Nutrition and Physical Activity, 7(1), 40. https:/ / doi.org/ 10.1186/ 1479-5868-7-40

Kubesch, S., Walk, L., Spitzer, M., Kammer, T., Lainburg, A., Heim, R., \& Hille, K. (2009). A 30Minute Physical Education Program Improves Students' Executive Attention. Mind, Brain, and Education, 3(4), 235-242. https:/ / doi.org/ 10.1111/ j.1751-228X.2009.01076.X

Mannino, G., Giunta, S., M ontefiori, V., Tamanza, G., lacolino, C., Novara, C., Rita, P., La Fiura, G., \& Bernardone,A. (2019). Healthy lifestyle, well-being, physical activity, sport, and scholastic/ academic performance: interactions and connections. World Futures, 75 (7), 462-479. https: / / doi.org/ 10.1080/ 02604027.2019 .1654772

Martínez-González, M. Á., Ruiz-Canela, M., Hruby, A., Liang, L., Trichopoulou, A., \& Hu, F. B. (2015). Intervention Trials with the Mediterranean Diet in Cardiovascular Prevention: Understanding Potential Mechanisms through Metabolomic Profiling. The Journal of Nutrition, 146(4), 913S-919S. https:// doi.org/ 10.3945/ jn. 115.219147

MECDE. (2014). Las cifras de la educación en España: Cuso 2011-2012.

Molina, J. J. M. (2021). Adherencia a la Dieta M editerránea, Actividad Física y su relación con el Nivel Socioeconómico en escolares de Primaria de la ca pital de Granada (The relationship of M editerranean diet adherence and Physical Activity engagement with Socioeconomic Status. Retos, 41, 485-491.

Ordax, J. R., \& Terrados, N. (2006). Métodos para la valoración de laActividad Física y el gasto energético en niños y adultos. Archivos de M edicina Del Deporte, XXIII(115), 365-377.

Physical Activity Guidelines Advisory Committee. (2018). Physical Activity Guidelines Advisory Committee Scientific Report. 
Rangel Caballero, L. G., Rojas Sánchez, L. Z., \& Gamboa Delgado, E. M. (2015). Actividad física y composición corporal en estudiantes universitarios de cultura física, deporte y recreación. Revista de La U niversidad Industrial de Santander. Salud, 47(3), 281290. https:/ / doi. org/ 10.18273/ revsal. v47n32015004

Rasberry, C. N., Lee, S. M., Robin, L., Laris, B. A., Russell, L. A., Coyle, K. K., \& Nihiser, A. J. (2011). The association between school-based physical activity, including physical education, and academic performance: A systematic review of the literature. Preventive Medicine, 52, S10-S20. https:/ / doi.org/ 10.1016/ j.ypmed.2011.01.027

Rizo-Baeza, M. M., González-Brauer, N. G., \& Cortés, E. (2014). Calidad de la dieta y estilos de vida en estudiantes de Ciencias de la Salud. N utrición Hospitalaria, 29(1), 153-157. https:/ / doi.org/ 10.3305/ nh.2014.29.1.6761

Rodrigo Vega, M., Ejeda M anzanera, J. M., Panero, G., del Pilar, M., \& M ijancos Gurruchaga, M. T. (2014). Cambios en la adherencia a la dieta mediterránea en estudiantes de los Grados de Enfermería y de Magisterio tras cursar una asignatura de Nutrición. Nutrición Hospitalaria, 30(5), 1173-1180. http:/ / dx. doi.org/ 10.3305/ nh. 2014.30.5.7714

Rosado, J. R., Fernández, Á. I., \& López, J. M. (2020). Evaluación de la práctica de actividad física, la adherencia a la dieta y el comportamiento y su relación con la calidad de vida en estudiantes de Educación Primaria. Retos: N uevasTendencias En Educación Física, Deporte y Recreación, 38, 24.

Rothon, C., Edwards, P. , Bhui, K., Viner, R. M., Taylor, S., \& Stansfeld, S. A. (2010). Physical activity and depressive symptoms in adolescents: a prospective study. BMC M edicine, 8(1), 32. https:/ / doi. org/ 10.1186/1741-7015-8-32

Salas-Salvadó, J., Rubio, M. A., Barbany, M., \& Moreno, B. (2007). Consenso SEEDO 2007 para la eva luación del sobrepeso y la obesidad y el establecimiento de criterios de intervención terapéutica. M edicina Clínica, 128(5), 184- 196. https:/ / doi.org/ 10.1016/ S0025-7753(07)72531-9

Salvador, G., Palma, I., Puchal, A., Vilà, M. C., Miserachs, M ., \& Illan, M. (2006). Entrevista dietética. Herramientas útiles para la recogida de datos. Revista de M edicina de La U niversidad de N avarra, 4655.

Serra-Majem, L., Ribas, L., N go, J., O rtega, R. M., García, A., Pérez-Rodrigo, C. \& \&Aranceta, J. (2004).
Food, youth and the Mediterranean diet in Spain. Development of KIDMED, M editerranean Diet Quality Index in children and adolescents. Public Health Nutrition, 7(7), 931-935. https:/ / doi. org/ 10.1079/ PHN 2004556

Soler, N. S. , Chávez, J. B. , \& Godoy-Cumillaf, A. (2019). Estado nutricional, ingesta dietética y niveles de glicemia en estudiantes universitarios de Pedagogía en Educación Física. Retos: N uevasTendencias En Educación Física, D eportey Recreación, 36, 510-514.

Solera Sánchez, A., \& Gamero Lluna, A. (2019). Hábitos saludables en universitarios de ciencias de la salud y de otras ramas de conocimiento: un estudio comparativo. Revista Española de Nutrición Humana y Dietética, 23(4), 271-282.

Stillman, C. M., Esteban-Cornejo, I., Brown, B. , Bender, C. M., \& Erickson, K. I. (2020). Effects of Exercise on Brain and Cognition Across Age Groups and Health States. Trends in N eurosciences, 43(7), 533- 543. https:/ / doi.org/ 10.1016/ j.tins.2020.04.010

U nited Nations O rganzation. (2011). N on communicable diseases deemed development challenge of «epidemic proportions». 66th General Assembly, GA(11138).

Wald, A., Muennig, P. A., 0 'Connell, K. A., \& Garber, C. E. (2014). Associations between healthy lifestyle behaviors and academic performance in US undergraduates: asecondary analysis of theAmerican College Health Association's N ational College Health Assessment II. American Journal of $\mathrm{H}$ ealth Promotion, 28(5), 298-305. https:/ / doi.org/ 10.4278/ ajhp. 120518-QUAN-265

W HO. (2010). Global recommendations on physical activity for health. Ginebra, Suiza.

W HO. (2015). 0 besidad y sobrepeso. Retrived from: http:/ / www.who.int/ es/ news-room/ fact-sheets/ detail/ obesity-and-overweight.

Zavala-Crichton, J. P., Esteban-Cornejo, I., Solis-U rra, P., M ora-Gonzalez, J., Cadenas-Sanchez, C., Rodriguez-Ayllon, M., Migueles, J. H., MolinaGarcia, P., Verdejo-Roman, J., Kramer, A. F., Hillman, C. H., Erickson, K. I., Catena, A., \& Ortega, F. B. (2020). Association of Sedentary Behavior with Brain Structure and Intelligence in Children with 0 verweight or 0 besity: The ActiveBrains Project. Journal of Clinical Medicine, 9(4). https:/ / doi.org/ 10.3390/ jcm9041101 